\title{
Effect of Different Drying Methods and Packing Material on Quality of Thyme (Thymus vulgaris L.) During Storage
}

\section{R.M.M. Yousef and A.M.A. Hamouda}

Medicinal and Aromatic Plants Department, Horticulture

Research Institute, Agricultural Research Centre, Cairo, Egypt.

\begin{abstract}
THIS INVESTIGATION was carried out during successive seasons of (2010/2011) and (2011/2012) at El-Kassassin Hort. Res. Station, Ismailia Governorate, Hort. Res. Institute, A. R. C., Egypt, to evaluate the effect of drying methods; oven at $45^{\circ} \mathrm{C}$, shade at $20 \pm$ $2^{\circ} \mathrm{C}$, greenhouse at $35 \pm 5^{\circ} \mathrm{C}$ and sun at $30 \pm 3^{\circ} \mathrm{C}$ and packing materials; carton boxes, glass jars, cotton bags and polyethylene bags during the different storage periods of 2, 4, 6, 8, 10 and 12 months on volatile oil, moisture content and herb pigments content, in the thyme (Thymus vulgaris $\mathrm{L}$ ) plant herb.
\end{abstract}

The highest values of volatile oil percentage was obtained from the oven drying method, while the lowest values was obtained from sun drying method. On the other side, the highest values of dry matter resulted from the shade drying, while the lowest resulted from the sun drying. Oven drying recorded the highest moisture content per $100 \mathrm{~g}$ fresh herb, while the lowest values recorded by shade drying in both seasons.

The G.L.C. of the volatile oil revealed that 12 compounds were identified as following Tricyclene, $\alpha$-Pinene, Camphene, $\alpha$-Terpinene, Limonene, 1,8-cineol, p- cymene, Camphor, Linalool, Borneol, Thymol and Carvacrol. The major componemts were Limonene and Thymol.

The oven drying combined with both glass jars or carton boxes recorded the highest values of chlorophyll (a), chlorophyll (b) and carotene content in herb, while the sun drying method combined with polyethylene bags recorded the lowest values in this respect during both seasons.

The storage period from 2 to 12 months decrease in the chlorophyll (a), chlorophyll (b) and carotene content of thyme herb in the two seasons.

Keywords: Thyme (Thymus vulgaris L.), drying methods, packing materials, storage periods and volatile oil.

Medicinal and aromatic plants are an important source of national income and foreign currency. They are among the most important agricultural export commodities that are in demand in European and other international markets. Moisture content (\%) is considered to be one of the most important factors influencing the quality attributes of dried herbs. Drying method of medicinal and 
aromatic plants is very important in meeting quality of plants and making them available for foreign and local markets. For this reason, suitable drying methods are needed, characterized in rapid reduction of the water content without affecting the quality of the active ingredients Bohm et al. (2006). The duration of drying process can vary from few hours to many weeks. Traditional drying methods, such as air drying in sun or under shade depend largely on the weather conditions, while artificial drying is more rapid and helps plant parts (flowers and leaves) retaining their color and aroma.

Rashed and Younis (2010) found that the highest significant dry matter \%, chlorophyll (a) and (b), volatile oil \% and oil constituents were recorded for polypropylene and polyvinyl chloride 2 shrink film to keep the quality of oregano herb until four weeks; the best drying system was the solar drying. Increasing storage period decreased the volatile oil percentage and the most of main components of fresh Origanum syriacum, L. herb.

Kassem et al. (2006) reported that some drying methods decreased essential oil content in lemongrass, oregano, spearmint and peppermint plants and the solar drying method was better than the natural drying (sun drying) and artificial drying (in oven at $45^{\circ} \mathrm{C}$ ). Mohamed, Mona (2010) showed that the shade drying method was the best treatment for producing the highest volatile oil percentage of parsley and dill plants, while oven drying gave the highest percentage of volatile oil components. On the other hand, sun drying method was the lowest one since it caused a decrease in the plant quality.

Thyme (Thymus vulgaris L.) belongs to the Lamiaceae (Labiatae) family, which comprises a large number of economically important plants such as mint, sweet basil, salvia, rosemary, marjoram, lavender beside thyme. Most of these plants grow well in Egypt as well in many other countries. It contains volatile oil of aromatic scent Simon et al. (1984)

Leaves and flowering tops of the plant are used to extract essential oil by steam distillation Guenther (1961). Volatile oil of Thymus vulgaris consists of different active medical ingredients used for carminative, antimicrobial, antiseptic, expectorant, diaphoretic actions, antigastra intestinal treatments. And some are used as additives in detergents, culinary (in food production) and perfumery industry Boon and Smith, (1999). The aim of this study is to evaluate the effect of the combination between drying methods and packing materials to obtained high pigments quality and volatile oil, content in dried thyme herbs during storage period of 12 months.

\section{Materials and Methods}

This investigation was carried out during the two successive seasons of (2010/2011) and (2011/2012) at El-Kassassin, Hort. Res. Station, Ismailia Egypt. J. Hort. Vol. 40, No.2 (2013) 
Governorate, Hort. Res. Institute, Agri. Res. Center, Ministry of Agric., Egypt to evaluate the effect of the combination between drying methods (oven, shade, green-house and sun) and packing materials (carton boxes, glass jars, cotton bags and polyethylene bags) during the different storage periods, .i.e. 2, 4, 6, 8, 10 and 12 months on volatile oil, moisture content, pigments content (chlorophyll a, b and carotene) in the fresh and dried herbs of thyme (Thymus vulgaris L ) plant.

The thyme plants (Thymus vulgaris L ) seedlings were obtained from the Medicinal and Aromatic Plants Section at El-Kanater El-Khairia, Kalubia Governorate, Hort. Res. Institute, A.R.C. The seedlings were $10-15 \mathrm{~cm}$ in length, with $10-12$ leaves and were transplanted on $1^{\text {st }}$ of March in rows $(60 \mathrm{~cm}$ between rows and $30 \mathrm{~cm}$ between plants).

The plants were cut twice in both seasons after three month from the transplanting at $10 \mathrm{~cm}$ from the soil surface. Plant samples was $4.8 \mathrm{k} .(4 \mathrm{drying}$ methods X 4 packing materials X 3 replicates) fresh herb of two cuttings and divided into four partition (1.2 k. fresh herb) for the each one drying method, each this the weight $(1.2 \mathrm{k}$.) were divided into four partition for the one packing material, each one packing need $300 \mathrm{~g}$. and divided for 3 replicates (100g.for one replicate).

This experiment included 16 treatments, which were the combinations between four drying methods and four packing materials as follows:

- Oven drying + Carton boxes.

- Oven drying + Glass jars.

- Oven drying + Cotton bags.

- Oven drying + Polyethylene.

- Shade drying + Carton boxes.

- Shade drying + Glass jars.

- Shade drying + Cotton bags.

- Shade drying + Polyethylene.

- Greenhouse drying + Carton boxes.

- 10.Greenhouse drying + Glass jars.

- 11.Greenhouse drying + Cotton bags.

- 12.Greenhouse drying + Polyethylene.

- 13.Sun drying + Carton boxes.

- 14.Sun drying + Glass jars.

- 15.Sun drying + Cotton bags.

- 16.Sun drying + Polyethylene.

These treatments were arranged in a randomized complete block design with three replicates.

Egypt. J. Hort. Vol. 40, No.2 (2013) 


\section{Drying methods}

Samples of thyme plant was divided into four sets, $1.2 \mathrm{~kg}$ of the fresh herb was taken to each one way of drying methods and put in the groups each $100 \mathrm{~g}$ form the following different drying procedures:

Oven drying: The fresh herbs were put on layer paper in oven at $45^{\circ} \mathrm{C}$ for 6 hours until the complete drying.

Shade drying: The fresh herbs were put in open ventilated area at $20 \pm 2^{\circ} \mathrm{C}$ in one layer paper for 15 days until the complete drying.

Green house drying: The fresh herbs were put on layer paper at $35 \pm 5^{\circ} \mathrm{C}$ for 5 days until the complete drying.

Sun drying: The fresh herbs were put on layer paper at $30 \pm 3^{\circ} \mathrm{C}$ for $7-10$ days until the complete drying.

\section{Packing materials}

After each drying method, the dried samples were separated to different packing materials. The packing materials were carton boxes, glass jars, cotton bags and polyethylene bags. Each containers type contains dry herb came out of $100 \mathrm{~g}$. fresh herb (FW) of thyme (Thymus vulgaris L). Four storage container of different material for each method of drying. The storage period is 12 months under room temperature conditions and the data recorded every 2 months in two seasons.

\section{Data recorded}

Herb dry matter (g / 100g FW) Plant samples of $100 \mathrm{~g}$ were chosen randomly from each treatment and dried at oven, shade, greenhouse and sun drying methods. The dry matter were recorded when its weight remained constant.

Moisture percentage (\%) Plants were chosen randomly from each treatment and their moisture $\%$ was calculated by drying $50 \mathrm{~g}$ of the samples at $70{ }^{\circ} \mathrm{C}$ in oven with air circulation until a constant weight.

Volatile oil percentage was determined in dry herb according to the method described in the Egyptian Pharmacopoeia(1984), using Clevenger's apparatus for the determination of essential oil according to Guenther (1961).

Gas chromatography; GLC analysis was determined for the volatile oil in 5 samples per plant under this study (1 sample from fresh herb and 4 samples from dry herb). The oil samples were performed using a programmed procedure. The quantitative estimation for each compound was based on the peak area measurement by triangulation Guenther and Joseph (1978).

Chlorophyll a b and carotene were determined in fresh and dry of herb samples (mg/g. D.W.) according to Mazumdar and Majumdar (2003).

Egypt. J. Hort. Vol. 40, No.2 (2013) 
Statistical analysis

Data were subjected to the statistical analysis and the differences between the means of the treatments were compared using the least significant differences (L.S.D) at $5 \%$ level as mentioned by Gomez and Gomez (1984).

\section{Results and Discussion}

Effect of drying methods on moisture (\%) and volatile oil (\%) at storage start

Data presented in Table 1 indicate the effect of drying methods oven, shade, greenhouse and sun on moisture and oil percentage of thyme (Thymus vulgaris, L) plant; oven and sun drying decreased moisture of fresh weight (FW) by 62.91 and $65.75 \%$ in the first and second seasons respectively, while the shade drying decreased FW by 59.57 and $60.51 \%$ in the two seasons, respectively. The highest values of oil percentage of 0.757 and $0.827 \%$ resulted from the green house and oven drying at $35 \pm 5^{\circ} \mathrm{C}$ in the first and second seasons respectively, while the lowest values of 0.613 and $0.660 \%$ were from sun drying at $30 \pm 3^{\circ} \mathrm{C}$ in both seasons, respectively, which means that sun drying causes more volatile oil loses. The results are in conformity with previous report from Karawya et al. (1977) who found that drying mint plants in the sun had decreased the essential oil content by $75 \%$. Refaat (1992) announced that laurel volatile oil percentage obtained from oven dried leaves at $40{ }^{\circ} \mathrm{C}$ was higher than that from shade and sun dried ones by 27.21 and $23.13 \%$ respectively, and concluded that more rapid drying produces higher oil percentage. Chang et al. (1996) mentioned that the yield and chemical composition of essential oils from Grenadian nutmegs was decreased with increasing drying temperatures to $45^{\circ} \mathrm{C}$ and this was associated with decreases in monoterpene hydrocarbon content. They announced maximum essential oil yields on a dry weight basis were obtained for nutmegs dried at 21$23{ }^{\circ} \mathrm{C}$. Muller et al. (1996) reported that medicinal plants are usually harvested at $80 \%$ moisture content and stored at $11 \%$. Refaat and Wahba (1998) stated that shade drying of lavender herb showed more conspicuous effect on the volatile oil content, since the decrement in oil percentage of sun and oven dried plants reached 12.07 and $30 \%$ respectively. Abdalla et al. (2002) noticed that, the highest percentage of essential oil of lemongrass (Cymbopogon citratus) was obtained from drying plant in shade, while the lowest one was obtained from drying in sun. Diaz-Maroto et al. (2002) recorded that oven drying at $45^{\circ} \mathrm{C}$ and air - drying at ambient temperature produced quite similar results and caused hardly any loss in volatile oil of bay leaf (Laurus nobilis L.) as compared to the fresh herb. Omidbaigi et al. (2004) reported that the flowers of Roman chamomile dried by three different drying methods of sun, shade and oven drying at $45^{\circ} \mathrm{C}$ and revealed that the oil content of the shade dried flowers was higher compared to sun or oven drying at $45^{\circ} \mathrm{C}$.

It is obvious that rapid artificial drying helps medicinal herbs in retaining quality and in satisfying growing demand of pharmaceutical industry. 
TABLE 1. Effect of drying methods on moisture and volatile oil percentage of fresh thyme in two season (2010-2011) and (2011- 2012).

\begin{tabular}{|l|c|c|c|c|c|c|}
\hline \multirow{2}{*}{$\begin{array}{l}\text { Drying } \\
\text { Method }\end{array}$} & \multicolumn{2}{|c|}{ Dry weight (g) } & \multicolumn{2}{c|}{ Moisture Content (\%) } & \multicolumn{2}{c|}{ Volatile oil \% } \\
\cline { 2 - 7 } & $\begin{array}{c}\mathbf{1}^{\text {st }} \\
\text { season }\end{array}$ & $\begin{array}{c}\text { 2nd } \\
\text { season }\end{array}$ & $\begin{array}{c}\mathbf{1}^{\text {st }} \\
\text { season }\end{array}$ & $\begin{array}{c}\text { 2nd } \\
\text { season }\end{array}$ & $\begin{array}{c}\mathbf{1}^{\text {st }} \\
\text { season }\end{array}$ & $\begin{array}{c}\text { 2nd } \\
\text { season }\end{array}$ \\
\hline Oven & 37.09 & 35.37 & 62.91 & 64.63 & 0.743 & 0.827 \\
\hline Shad & 40.43 & 39.49 & 59.57 & 60.51 & 0.703 & 0.733 \\
\hline Green house & 39.78 & 38.08 & 60.22 & 61.92 & 0.757 & 0.800 \\
\hline Sun & 38.27 & 34.25 & 61.73 & 65.75 & 0.613 & 0.660 \\
\hline L.S.D. at 5\% & 1.22 & 0.73 & 1.22 & 0.73 & 0.024 & 0.009 \\
\hline
\end{tabular}

Effect of drying methods on the volatile oil components (\%) at storage start

The results of G.L.C. analysis are shown in Table 2. Data showed the effect of drying methods (oven at $45^{\circ} \mathrm{C}$, shade at $20 \pm 2{ }^{\circ} \mathrm{C}$, greenhouse at $35 \pm 5^{\circ} \mathrm{C}$ and sun at $30 \pm 3{ }^{\circ} \mathrm{C}$ ) on the volatile oil constituents of fresh thyme herb. The drying method had a significant effect on the proportion of the total main components in volatile oil of thyme plant. The G.L.C. of the volatile oil revealed that 12 compounds were obtained in the oil as follows: Tricyclene, $\alpha$ - Pinene, Camphene, $\alpha$-Terpinene, Limonene, 1,8-cineol, P-Cymene, Camphor, Linalool, Borneol, Thymol and Carvacrol.

The main components of thyme essential oil were Camphene, Limonene and Thymol. The total identified compounds were constituted 97.950, 97.471, 89.071, 93.191 and $64.377 \%$ in the oil of fresh herb, oven, shade, greenhouse and sun drying methods, respectively. The data presented in Table 2 showed that each drying method had different mode of action on the constellation of the volatile oil compounds; each volatile oil component reacts different under certain drying method and no regular trend can be concluded; a certain (Tricyclene) component can be increased by one method (oven), decreased by another (green house) while posted three fold high by third method (sun drying). Thymol, as other example, remain in similar level by using oven, shade and green house drying method, while decreased by three fold when using sun drying. wever, the highest value of Camphene $(7.269 \%)$ obtained from sun drying at $30 \pm 3{ }^{\circ} \mathrm{C}$ while the lowest was $(3.517 \%)$ from drying at oven at $45^{\circ} \mathrm{C}$. The highest value of Limonene $(39.393 \%)$ gave from greenhouse drying at $35 \pm 5{ }^{\circ} \mathrm{C}$, while the lowest was $(14.973 \%)$ from sun drying at $30 \pm 3{ }^{\circ} \mathrm{C}$. The highest value of $\mathrm{P}$ Cymene $(8.603 \%)$ from fresh herb, while the lowest was $(3.447 \%)$ from drying at oven at $45{ }^{\circ} \mathrm{C}$, the highest value of Thymol was $(23.693 \%)$ from drying in oven at $45{ }^{\circ} \mathrm{C}$, while the lowest was $(5.747 \%)$ from drying in sun and the highest value of Carvacrol $(8.590 \%)$ gave from greenhouse drying at $35 \pm 5{ }^{\circ} \mathrm{C}$, while the lowest was $(0.009 \%)$ from sun drying at $30 \pm 3{ }^{\circ} \mathrm{C}$.

Egypt. J. Hort. Vol. 40, No.2 (2013) 
TABLE 2. Effect of drying method on volatile oil components (\%) of Thymus vulgaris L. plant.

\begin{tabular}{|c|c|c|c|c|c|}
\hline \multirow[b]{2}{*}{$\begin{array}{l}\text { Volatile oil } \\
\text { components }\end{array}$} & \multicolumn{5}{|c|}{ Volatile oil components ( in \%) after drying methods } \\
\hline & $\begin{array}{l}\text { Fresh } \\
\text { herb }\end{array}$ & $\begin{array}{c}\text { Oven } \\
\text { at } 45^{\circ} \mathrm{C}\end{array}$ & $\begin{array}{c}\text { Shade } \\
\text { at } 20 \pm 2{ }^{\circ} \mathrm{C}\end{array}$ & $\begin{array}{l}\text { Greenhouse } \\
\text { at } 35 \pm 5^{\circ} \mathrm{C}\end{array}$ & $\begin{array}{c}\text { Sun } \\
\text { at } 30 \pm 3^{\circ} \mathrm{C}\end{array}$ \\
\hline Tricyclene & 2.124 & 2.160 & 1.751 & 0.769 & 6.730 \\
\hline$\alpha$-Pinene & 3.909 & 4.017 & 3.794 & 5.370 & 9.627 \\
\hline Camphene & 4.162 & 3.517 & 4.363 & 4.060 & 7.269 \\
\hline$\alpha$-Terpinene & - & 0.892 & - & - & - \\
\hline Limonene & 35.78 & 34.270 & 33.941 & 39.393 & 14.973 \\
\hline 1,8 - Cineol & 5.530 & 11.387 & 6.338 & - & - \\
\hline P - Cymene & 8.603 & 3.447 & 4.770 & 3.692 & 7.388 \\
\hline Camphor & 1.804 & 1.819 & - & 3.960 & - \\
\hline Linalool & 5.736 & 6.015 & 7.096 & 2.467 & 7.912 \\
\hline Borneol & 6.132 & 4.538 & 3.145 & 2.088 & 4.722 \\
\hline Thymol & 22.755 & 23.693 & 21.083 & 22.762 & 5.747 \\
\hline Carvacrol & 1.415 & 1.716 & 2.790 & 8.590 & 0.009 \\
\hline Total Known & 97.950 & 97.471 & 89.071 & 93.151 & 64.377 \\
\hline
\end{tabular}

Effect of drying methods on chlorophyll (a) content ( $m g / g$ D.W.)

Chlorophyll content is considered as quality indicator of freshness. Data in Table (3- a) showed that the chlorophyll (a) content of thyme herb at different drying methods; the oven drying gave the highest values of chlorophyll (a) by 1.83 and $1.26 \mathrm{mg} / \mathrm{g} \mathrm{DW}$, while the sun drying gave the lowest values of chlorophyll (a) by 1.69 and $1.13 \mathrm{mg} / \mathrm{g}$ DW during the first and second seasons, respectively. These may be due to the degradation effect of light and heat that is more drastic in sun than in oven (heat factor) than in shade (absence of light and heat factor), which is liable for oxidation, polymerization or resinification. Similar results were obtained by Mohamed, Mona (2010) on parsley and dill and showed that aromatic herbs must be dried rapidly to retain their color.

TABLE 3-a. Effect of drying methods on chlorophyll a of thyme herb after different drying methods during the two seasons of 2010-2011 and 2011-2012 .

\begin{tabular}{|l|c|c|c|c|c|c|c|}
\hline \multirow{2}{*}{ Chlorophylla } & \multirow{2}{*}{ Seasons } & $\begin{array}{c}\text { Fresh } \\
\text { herb }\end{array}$ & Oven & Shad & $\begin{array}{c}\text { Green } \\
\text { house }\end{array}$ & Sun & $\begin{array}{c}\text { L.S.D. } \\
\mathbf{5 \%}\end{array}$ \\
\hline \multirow{2}{*}{$\mathrm{mg} / \mathrm{g}$ D.W } & $1^{\text {st }}$ season & 1.60 & 1.83 & 1.71 & 1.79 & 1.69 & 0.00002 \\
\cline { 2 - 9 } & $2^{\text {nd }}$ season & 1.12 & 1.26 & 1.24 & 1.29 & 1.13 & 0.007 \\
\hline
\end{tabular}

Egypt. J. Hort. Vol. 40, No.2 (2013) 
Concerning, the effect of the drying methods and packing materials treatments throughout 12 months storage periods in retaining the freshness color after drying with different methods, the chlorophyll (a) content is used as indicator. The data in Table (3-b) showed that, the effect of this interaction treatments resulted significant effect on chlorophyll (a); the glass jars as packing materials retain the highest value of chlorophyll (a) content dried under all different drying methods (oven, shade, greenhouse and sun) throughout storage period of 12 months when compared with the other packing materials. While, the lowest value obtained by using the polyethylene bags as packing materials with different drying methods compared with the others packing materials in both seasons throughout storage period of 12 months. This is mainly due to the structure of transparent polyethylene bags, which gives high penetration level of light more than the carton boxes or the cotton bags which affects the sensitive molecular structure of chlorophyll badly.

These results are in agreement with those obtained by of Rashed (2002) on dill and parsley and Al-Kershi (2003) on spearmint and sweet basil herbs, indicated that stored in polyethylene bags reduced chlorophyll "a+b". Also Mohamed (2005) on marjoram and rosemary leaves, reported that polyethylene bags had the lowest values of chlorophyll content.

Also, it could be noticed that there was a gradual significant decrease in chlorophyll (a) content of thyme herb during the storage periods from 2 to 12 months in the two seasons. These results were parallel to those obtained by Hassan et al. (1989) on peppermint and El-Kady (2003) on basil and marjoram, found that during storage up to nine months at room temperature, the chlorophyll content was gradually degraded.

Effect of drying methods, packing materials treatments and different storage periods on chlorophyll (b) content $(\mathrm{mg} / \mathrm{g} \mathrm{D.W}$.)

Data in Table (4-a) showed the effect of drying methods at storage start on chlorophyll (b) content, as indicater for freshness; the data inducted that the drying methods have significant effect on chlorophyll (b) content, it could be noticed that the oven dying method $45^{\circ} \mathrm{C}$ gave the highest chlorophyll (b) content with 1.47 and $1.30 \mathrm{mg} / \mathrm{g}$ D.W., respectively during the two seasons, compared with the other drying methods. While, the sun drying gave the lowest values of chlorophyll (b) content of 1.22 and $1.17 \mathrm{mg} / \mathrm{g} \mathrm{D.W}$., respectively, during the two seasons. This is in accordance with the findings of Musa et al. (2004) found that sun drying method was the lowest one since it caused a decrease in plant quality i.e. chlorophyll content. The same results obtained by Mohamed, Mona (2010) on parsley and dill.

Egypt. J. Hort. Vol. 40, No.2 (2013) 
EFFECT OF DIFFERENT DRYING METHODS AND PACKING ...

TABLE 3-b. Effect of packing materials and different storage periods after drying methods on chlorophyll a of thyme in the 2 seasons of 2010-2011 and 2011- 2012.

\begin{tabular}{|c|c|c|c|c|c|c|c|c|c|}
\hline \multirow{4}{*}{ 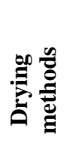 } & \multirow{4}{*}{ Packing material } & \multicolumn{6}{|c|}{ Chlorophyll a (mg/g D.W.) } & \multirow{3}{*}{$\begin{array}{l}\text { Sum of } \\
\text { storage } \\
\text { Period }\end{array}$} & \multirow{3}{*}{$\begin{array}{c}\text { Sum of } \\
\text { drying } \\
\text { Method }\end{array}$} \\
\hline & & \multicolumn{6}{|c|}{ Storage periods (months) } & & \\
\hline & & 2 & 4 & 6 & 8 & 10 & 12 & & \\
\hline & & & & & & season & & & \\
\hline \multirow{4}{*}{ రี } & Carton boxes & 1.797 & 1.583 & 1.430 & 1.440 & 1.250 & 1.207 & 9 & \multirow{4}{*}{34} \\
\hline & Glass jars & 1.803 & 1.747 & 1.570 & 1.490 & 1.417 & 1.350 & 9 & \\
\hline & Cotton bags & 1.730 & 1.583 & 1.510 & 1.243 & 1.213 & 1.193 & 8 & \\
\hline & Polyethylene bags & 1.650 & 1.357 & 1.360 & 1.033 & 1.033 & 1.173 & 8 & \\
\hline \multirow{4}{*}{ 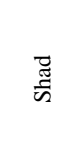 } & Carton boxes & 1.557 & 1.527 & 1.423 & 1.410 & 1.337 & 1.380 & 9 & \multirow{4}{*}{35} \\
\hline & Glass jars & 1.667 & 1.587 & 1.550 & 1.527 & 1.480 & 1.427 & 9 & \\
\hline & Cotton bags & 1.543 & 1.507 & 1.450 & 1.477 & 1.353 & 1.283 & 9 & \\
\hline & Polyethylene bags & 1.527 & 1.383 & 1.337 & 1.250 & 1.160 & 1.060 & 8 & \\
\hline \multirow{4}{*}{ 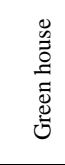 } & Carton boxes & 1.733 & 1.440 & 1.407 & 1.140 & 1.080 & 1.040 & 8 & \multirow{4}{*}{32} \\
\hline & Glass jars & 1.767 & 1.517 & 1.490 & 1.417 & 1.293 & 1.183 & 9 & \\
\hline & Cotton bags & 1.643 & 1.323 & 1.250 & 1.217 & 1.097 & 1.033 & 8 & \\
\hline & Polyethylene bags & 1.627 & 1.260 & 1.177 & 1.160 & 1.000 & 0.910 & 7 & \\
\hline \multirow{5}{*}{ 志 } & Carton boxes & 1.600 & 1.313 & 1.217 & 1.180 & 1.103 & 1.073 & 7 & \multirow{4}{*}{28} \\
\hline & Glass jars & 1.663 & 1.297 & 1.257 & 1.243 & 1.177 & 1.120 & 8 & \\
\hline & Cotton bags & 1.597 & 1.260 & 1.150 & 1.160 & 1.073 & 1.033 & 7 & \\
\hline & Polyethylene bags & 1.470 & 1.057 & 1.033 & 1.007 & 0.973 & 0.860 & 6 & \\
\hline & L.S.D. at $5 \%$ & 0.027 & 0.069 & 0.036 & 0.041 & 0.044 & 0.037 & & \\
\hline \multicolumn{2}{|c|}{ Sum Drying Period X Storage } & 26.37 & 22.74 & 21.61 & 20.39 & 19.04 & 18.33 & & \\
\hline & & \multicolumn{8}{|c|}{ Second season } \\
\hline \multirow{4}{*}{ 苂 } & Carton boxes & 1.260 & 1.223 & 1.143 & 1.077 & 0.976 & 0.849 & 7 & \multirow{4}{*}{27} \\
\hline & Glass jars & 1.320 & 1.300 & 1.233 & 1.137 & 1.018 & 0.976 & 7 & \\
\hline & Cotton bags & 1.203 & 1.147 & 1.133 & 1.063 & 0.923 & 0.639 & 6 & \\
\hline & Polyethylene bags & 1.477 & 1.390 & 1.297 & 1.187 & 1.030 & 0.909 & 7 & \\
\hline \multirow{4}{*}{$\begin{array}{l}\vec{\Xi} \\
\text { ज्ञ }\end{array}$} & Carton boxes & 1.347 & 1.263 & 1.110 & 1.067 & 0.981 & 0.852 & 7 & \multirow{4}{*}{27} \\
\hline & Glass jars & 1.217 & 1.307 & 1.233 & 1.133 & 0.993 & 0.966 & 7 & \\
\hline & Cotton bags & 1.417 & 1.133 & 1.150 & 1.047 & 0.796 & 0.652 & 6 & \\
\hline & Polyethylene bags & 1.513 & 1.383 & 1.300 & 1.233 & 1.002 & 0.892 & 7 & \\
\hline \multirow{4}{*}{ 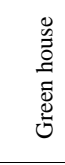 } & Carton boxes & 1.277 & 1.217 & 1.173 & 1.067 & 1.053 & 0.820 & 7 & \multirow{4}{*}{27} \\
\hline & Glass jars & 1.330 & 1.310 & 1.267 & 1.100 & 1.070 & 0.843 & 7 & \\
\hline & Cotton bags & 1.233 & 1.160 & 1.160 & 0.963 & 0.863 & 0.695 & 6 & \\
\hline & Polyethylene bags & 1.307 & 1.253 & 1.267 & 1.187 & 1.107 & 0.969 & 7 & \\
\hline \multirow{4}{*}{$\Xi$} & Carton boxes & 1.163 & 1.140 & 1.130 & 1.073 & 0.856 & 0.478 & 6 & \multirow{4}{*}{23} \\
\hline & Glass jars & 1.210 & 1.340 & 1.257 & 1.083 & 0.985 & 0.591 & 6 & \\
\hline & Cotton bags & 1.083 & 1.193 & 1.103 & 0.985 & 0.671 & 0.353 & 5 & \\
\hline & Polyethylene bags & 1.207 & 1.263 & 1.253 & 1.077 & 1.002 & 0.673 & 6 & \\
\hline & L.S.D. at $5 \%$ & 0.060 & 0.033 & 0.035 & 0.033 & 0.050 & 0.040 & & \\
\hline Sum I & rying Period X Storage & 20.50 & 20.02 & 19.20 & 17.47 & 15.00 & 12.15 & & \\
\hline
\end{tabular}

Egypt. J. Hort. Vol. 40, No.2 (2013) 
TABLE 4-a. Effect of drying methods on chlorophyll b of thyme herb during the two seasons of 2010-2011 and 2011-2012.

\begin{tabular}{|c|c|c|c|c|c|c|c|}
\hline \multirow[b]{2}{*}{ Chlorophyll b } & \multirow[b]{2}{*}{ Season } & \multicolumn{6}{|c|}{ Drying methods } \\
\hline & & $\begin{array}{c}\text { Fresh } \\
\text { herb }\end{array}$ & Oven & Shad & $\begin{array}{l}\text { Green } \\
\text { house }\end{array}$ & Sun & $\begin{array}{c}\text { L.S.D. } \\
\mathbf{5 \%}\end{array}$ \\
\hline \multirow{2}{*}{ mg/g D.W } & $1^{\text {st }}$ season & 1.19 & 1.47 & 1.29 & 1.23 & 1.22 & 0.00005 \\
\hline & $2^{\text {nd }}$ & 1.07 & 1.30 & 1.22 & 1.41 & 1.17 & 0.0003 \\
\hline
\end{tabular}

Concerning, the effect of the drying methods and packing materials treatments throughout 12 months storage periods in retaining the freshness color after drying with different methods, the data in Table (4-b) showed the effect of the drying methods and packing materials treatments on the chlorophyll (b) content; it was significantly affected with the interaction treatments. The interaction effect showed similar trend as in case of chlorophyll (a); oven drying method at $45{ }^{\circ} \mathrm{C}$ of thyme herb which stored in glass jars as packing material gave the highest values of chlorophyll (b) content during the two seasons. Also, using the glass jar as packing materials combined with the other drying methods through the 12 months storage period gave the highest values of chlorophyll (b) content. While, the data showed that the sun drying method of thyme which stored in polyethylene bags as packing materials gave the lowest values of chlorophyll (b) content during the tow seasons.

This is mainly due to the structure of transparent polyethylene bags, which gives high penetration level of light more than the carton boxes or the cotton bags which affects the sensitive molecular structure of chlorophyll badly. The longest storage period of 12 months decreased the chlorophyll (b) content of thyme herb in the two seasons the loss increased with increasing period of storage.

These results were parallel with those obtained by Hassan et al. (1989), on peppermint, Abd El-Latif et al. (2001), on parsley, coriander and peppermint and El-Kady (2003) on basil and marjoram. Mohamed (2005) on marjoram and rosemary.

Effect of drying methods, packing materials treatments and different storage periods on carotene content ( $\mathrm{mg} / \mathrm{g} \mathrm{D}$.W.)

As for the effect of drying methods in zero time, the data in Table (5-a) indicated that the carotene content was significantly affected with the drying methods. The maximum values of carotene content obtained when using the oven drying method at $45{ }^{\circ} \mathrm{C}$ resulted $(1.15$ and $1.02 \mathrm{mg} / \mathrm{g}$ D.W. $)$ during the first and second seasons, respectively. While the lowest values when using the sun drying method at $30 \pm 5{ }^{\circ} \mathrm{C}$ resulted $(1.0$ and $0.87 \mathrm{mg} / \mathrm{g} \mathrm{DW})$ during the first and second seasons compared to the shade and greenhouse drying methods.

The obtained results are in harmony with Karabulut et al. (2007) on apricot (Prunus armenica L.) and Mohamed, Mona (2010) on parsley and dill.

Egypt. J. Hort. Vol. 40, No.2 (2013) 
EFFECT OF DIFFERENT DRYING METHODS AND PACKING ...

TABLE 4-b. Effect of packing materials and different storage periods after drying methods on Chlorophyll b of thyme in the two seasons of 2010/2010 and 2010/2011.

\begin{tabular}{|c|c|c|c|c|c|c|c|c|c|}
\hline \multirow{4}{*}{ 象 } & \multirow{4}{*}{ Packing material } & \multicolumn{6}{|c|}{ Chlorophyll b (mg/ g D.W.) } & \multirow{3}{*}{$\begin{array}{l}\text { Sum of } \\
\text { storage } \\
\text { Period }\end{array}$} & \multirow{3}{*}{$\begin{array}{l}\text { Sum of } \\
\text { drying } \\
\text { Method }\end{array}$} \\
\hline & & \multicolumn{6}{|c|}{ Storage periods (months) } & & \\
\hline & & 2 & 4 & 6 & 8 & 10 & 12 & & \\
\hline & & \multicolumn{8}{|c|}{ First season } \\
\hline \multirow{4}{*}{ రั๊ } & Carton boxes & 1.230 & 1.063 & 1.023 & 1.017 & 0.933 & 0.830 & 6 & \multirow{4}{*}{24} \\
\hline & Glass jars & 1.190 & 1.157 & 1.097 & 0.993 & 0.973 & 0.937 & 6 & \\
\hline & Cotton bags & 1.187 & 1.033 & 1.080 & 1.070 & 0.897 & 0.927 & 6 & \\
\hline & Polyethylene bags & 1.220 & 1.180 & 1.070 & 0.910 & 0.863 & 0.850 & 6 & \\
\hline \multirow{4}{*}{ 胥 } & Carton boxes & 1.220 & 1.140 & 1.043 & 0.913 & 0.880 & 0.863 & 6 & \multirow{4}{*}{24} \\
\hline & Glass jars & 1.220 & 1.180 & 1.083 & 1.017 & 1.000 & 0.973 & 6 & \\
\hline & Cotton bags & 1.230 & 1.127 & 1.033 & 1.053 & 0.907 & 0.907 & 6 & \\
\hline & Polyethylene bags & 1.173 & 0.987 & 0.877 & 1.087 & 0.847 & 0.813 & 6 & \\
\hline \multirow{4}{*}{ 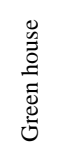 } & Carton boxes & 1.247 & 1.087 & 1.050 & 1.050 & 1.000 & 1.030 & 6 & \multirow{4}{*}{26} \\
\hline & Glass jars & 1.250 & 1.067 & 1.077 & 1.057 & 1.040 & 1.030 & 7 & \\
\hline & Cotton bags & 1.210 & 1.107 & 1.040 & 1.087 & 1.060 & 1.070 & 7 & \\
\hline & Polyethylene bags & 1.163 & 1.093 & 1.013 & 0.923 & 0.910 & 0.890 & 6 & \\
\hline \multirow{4}{*}{$\Xi$} & Carton boxes & 1.213 & 1.413 & 1.030 & 0.990 & 0.963 & 0.943 & 6 & \multirow{4}{*}{24} \\
\hline & Glass jars & 1.183 & 1.123 & 1.087 & 1.333 & 1.030 & 0.950 & 6 & \\
\hline & Cotton bags & 1.190 & 1.077 & 1.027 & 1.023 & 0.987 & 0.960 & 6 & \\
\hline & Polyethylene bags & 1.203 & 1.063 & 0.980 & 0.893 & 0.850 & 0.853 & 6 & \\
\hline & L.S.D. at $5 \%$ & 0.015 & 0.199 & 0.031 & 0.192 & 0.034 & 0.039 & & \\
\hline \multicolumn{2}{|c|}{$\begin{array}{c}\text { Sum Drying Period X } \\
\text { Storage }\end{array}$} & 19.33 & 17.90 & 16.61 & 16.42 & 15.00 & 14.83 & & \\
\hline & & & & & Sec & season & & & \\
\hline \multirow{4}{*}{ ర్ } & Carton boxes & 1.297 & 1.270 & 1.190 & 1.090 & 0.025 & 0.574 & 5 & \multirow{4}{*}{20} \\
\hline & Glass jars & 1.340 & 1.313 & 1.120 & 1.027 & 0.033 & 0.620 & 5 & \\
\hline & Cotton bags & 1.247 & 1.253 & 1.100 & 0.976 & 0.025 & 0.513 & 5 & \\
\hline & Polyethylene bags & 1.203 & 1.187 & 1.067 & 0.886 & 0.033 & 0.292 & 5 & \\
\hline \multirow{4}{*}{ 苟 } & Carton boxes & 1.247 & 1.207 & 1.183 & 1.057 & 0.025 & 0.635 & 5 & \multirow{4}{*}{20} \\
\hline & Glass jars & 1.217 & 1.210 & 1.123 & 1.137 & 0.033 & 0.648 & 5 & \\
\hline & Cotton bags & 1.203 & 1.180 & 1.153 & 0.958 & 0.025 & 0.419 & 5 & \\
\hline & Polyethylene bags & 1.160 & 1.157 & 1.090 & 0.853 & 0.033 & 0.308 & 5 & \\
\hline \multirow{4}{*}{ 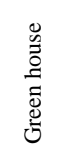 } & Carton boxes & 1.347 & 1.320 & 1.227 & 1.127 & 0.025 & 0.514 & 6 & \multirow{4}{*}{22} \\
\hline & Glass jars & 1.413 & 1.400 & 1.320 & 1.163 & 0.033 & 0.539 & 6 & \\
\hline & Cotton bags & 1.323 & 1.293 & 1.250 & 0.993 & 0.025 & 0.472 & 5 & \\
\hline & Polyethylene bags & 1.197 & 1.200 & 1.143 & 0.849 & 0.033 & 0.290 & 5 & \\
\hline \multirow{4}{*}{$\Xi$} & Carton boxes & 1.197 & 1.180 & 1.160 & 0.986 & 0.025 & 0.318 & 5 & \multirow{4}{*}{19} \\
\hline & Glass jars & 1.200 & 1.183 & 1.130 & 0.987 & 0.033 & 0.338 & 5 & \\
\hline & Cotton bags & 1.147 & 1.137 & 1.097 & 0.884 & 0.025 & 0.272 & 5 & \\
\hline & Polyethylene bags & 1.127 & 1.110 & 1.080 & 0.758 & 0.033 & 0.171 & 4 & \\
\hline & L.S.D. at $5 \%$ & 0.024 & 0.031 & 0.033 & 0.025 & 0.062 & 0.033 & & \\
\hline & $\begin{array}{l}\mathrm{n} \text { Drying Period X } \\
\text { Storage }\end{array}$ & 19.87 & 19.60 & 18.43 & 15.73 & 0.46 & 6.92 & & \\
\hline
\end{tabular}


TABLE 5-a. Effect of drying methods on carotene of thyme herb during the two seasons of 2010-2011 and 2011-2012.

\begin{tabular}{|c|c|c|c|c|c|c|c|}
\hline \multirow[b]{2}{*}{ Carotene } & \multirow[b]{2}{*}{ Seasons } & \multirow{2}{*}{$\begin{array}{c}\text { Fresh } \\
\text { herb }\end{array}$} & \multicolumn{5}{|c|}{ Drying methods } \\
\hline & & & Oven & Shade & $\begin{array}{l}\text { Green } \\
\text { house }\end{array}$ & Sun & $\begin{array}{c}\text { L.S.D. } \\
\mathbf{5 \%}\end{array}$ \\
\hline \multirow{2}{*}{ mg/g D.W } & $1^{s t}$ season & 0.95 & 1.15 & 1.11 & 1.05 & 1.00 & 0.0006 \\
\hline & $1^{s t}$ season & 0.82 & 1.02 & 0.97 & 0.95 & 0.87 & 0.0004 \\
\hline
\end{tabular}

Also, the data in Table 5-b showed that, the drying methods and packing materials treatments had significant effect in carotene content through the 12 months storage periods. The highest values of carotene content of thyme herb resulted by using the oven drying method at $45{ }^{\circ} \mathrm{C}$ and stored in glass jars followed by cartoon boxes and cotton bags through 12 months storage periods. While, the polyethylene bags resulted the lowest carotene values under the similar conditions in the two seasons. The ethylene bags hastened the rate of carotene degradation. This is mainly due to the structure of transparent polyethylene bags, which gives high penetration level of light more than the cartoon boxes or the cotton bags which affects the sensitive molecular structure of carotene badly. Concerning the effect of storage periods, it could be noticed that there was a gradual significant decrease in carotene content of thyme herb during the storage periods from 2 to 12 months. The decrement percentages were 51.57 and $37.80 \%$ compared the zero time (after drying methods) in the first and second seasons respectively, when stored for 12 month under the oven drying methods and using the glass jars in the two seasons. Similar results, were obtained by Mohamed (2005) on marjoram and rosemary and Mohamed, Mona (2010) on parsley and dill.

\section{Conclusion}

The results showed that using rapid oven drying at $45^{\circ} \mathrm{C}$ and jar glasses as packing material were the best drying method and packing material in retaining higher volatile oil content and freshness of stored thyme herb, even though the longer the storage period the lower the quality; a storage period of 12 months may decrease the quality by $50 \%$. 
EFFECT OF DIFFERENT DRYING METHODS AND PACKING ...

TABLE 5-b. Effect of packing materials and different storage periods after drying methods on carotene of thyme herb in the two seasons of 2010/2011 and 2011/2012.

\begin{tabular}{|c|c|c|c|c|c|c|c|c|c|}
\hline \multirow{4}{*}{ 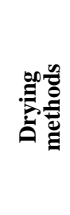 } & \multirow{4}{*}{ Packing material } & \multicolumn{6}{|c|}{ Carotene (mg/ gm D.W.) } & \multirow{3}{*}{$\begin{array}{l}\text { Sum of } \\
\text { storage } \\
\text { Period }\end{array}$} & \multirow{3}{*}{$\begin{array}{l}\text { Sum of } \\
\text { drying } \\
\text { Method }\end{array}$} \\
\hline & & \multicolumn{6}{|c|}{ Storage periods (months) } & & \\
\hline & & 2 & 4 & 6 & 8 & 10 & 12 & & \\
\hline & & & & & Fir & season & & & \\
\hline \multirow{4}{*}{ ర̃ } & Carton boxes & 1.100 & 0.913 & 0.827 & 0.733 & 0.580 & 0.557 & 5 & \multirow{4}{*}{19} \\
\hline & Glass jars & 1.130 & 0.867 & 0.853 & 0.777 & 0.600 & 0.563 & 5 & \\
\hline & Cotton bags & 1.033 & 0.820 & 0.807 & 0.697 & 0.643 & 0.587 & 5 & \\
\hline & Polyethylene bags & 0.970 & 0.787 & 0.733 & 0.630 & 0.540 & 0.477 & 4 & \\
\hline \multirow{4}{*}{ 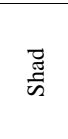 } & Carton boxes & 0.967 & 0.860 & 0.820 & 0.720 & 0.747 & 0.630 & 5 & \multirow{4}{*}{19} \\
\hline & Glass jars & 1.000 & 0.930 & 0.907 & 0.827 & 0.783 & 0.700 & 5 & \\
\hline & Cotton bags & 0.923 & 0.837 & 0.793 & 0.700 & 0.690 & 0.633 & 5 & \\
\hline & Polyethylene bags & 0.893 & 0.827 & 0.757 & 0.610 & 0.523 & 0.467 & 4 & \\
\hline \multirow{4}{*}{ 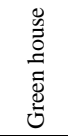 } & Carton boxes & 0.927 & 0.820 & 0.807 & 0.707 & 0.690 & 0.597 & 5 & \multirow{4}{*}{18} \\
\hline & Glass jars & 0.970 & 0.860 & 0.857 & 0.773 & 0.713 & 0.617 & 5 & \\
\hline & Cotton bags & 0.917 & 0.803 & 0.793 & 0.600 & 0.587 & 0.500 & 4 & \\
\hline & Polyethylene bags & 0.857 & 0.777 & 0.737 & 0.553 & 0.517 & 0.503 & 4 & \\
\hline \multirow{4}{*}{$\Xi$} & Carton boxes & 0.857 & 0.740 & 0.760 & 0.593 & 0.690 & 0.600 & 4 & \multirow{4}{*}{17} \\
\hline & Glass jars & 0.890 & 0.777 & 0.760 & 0.697 & 0.763 & 0.693 & 5 & \\
\hline & Cotton bags & 0.830 & 0.690 & 0.693 & 0.577 & 0.593 & 0.560 & 4 & \\
\hline & Polyethylene bags & 0.787 & 0.673 & 0.643 & 0.550 & 0.527 & 0.467 & 4 & \\
\hline & L.S.D. at $5 \%$ & 0.014 & 0.030 & 0.030 & 0.023 & 0.020 & 0.030 & & \\
\hline \multicolumn{2}{|c|}{ Sum Drying Period X Storage } & 15.05 & 12.98 & 12.55 & 10.74 & 10.19 & 9.15 & & \\
\hline & & \multicolumn{8}{|c|}{ Second season } \\
\hline \multirow{4}{*}{ ర̃ } & Carton boxes & 0.907 & 0.867 & 0.857 & 0.730 & 0.540 & 0.510 & 4 & \multirow{4}{*}{17} \\
\hline & Glass jars & 0.920 & 0.840 & 0.897 & 0.803 & 0.650 & 0.580 & 5 & \\
\hline & Cotton bags & 0.810 & 0.833 & 0.683 & 0.697 & 0.593 & 0.477 & 4 & \\
\hline & Polyethylene bags & 0.783 & 0.803 & 0.760 & 0.683 & 0.517 & 0.383 & 4 & \\
\hline \multirow{4}{*}{$\overrightarrow{\tilde{J}}$} & Carton boxes & 0.867 & 0.807 & 0.753 & 0.787 & 0.693 & 0.627 & 5 & \multirow{4}{*}{18} \\
\hline & Glass jars & 0.887 & 0.903 & 0.823 & 0.763 & 0.743 & 0.650 & 5 & \\
\hline & Cotton bags & 0.823 & 0.813 & 0.730 & 0.680 & 0.590 & 0.510 & 4 & \\
\hline & Polyethylene bags & 0.740 & 0.740 & 0.727 & 0.597 & 0.513 & 0.417 & 4 & \\
\hline \multirow{4}{*}{ 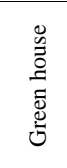 } & Carton boxes & 0.930 & 0.893 & 0.810 & 0.647 & 0.610 & 0.560 & 4 & \multirow{4}{*}{17} \\
\hline & Glass jars & 0.947 & 0.927 & 0.857 & 0.757 & 0.697 & 0.667 & 5 & \\
\hline & Cotton bags & 0.827 & 0.760 & 0.777 & 0.680 & 0.507 & 0.430 & 4 & \\
\hline & Polyethylene bags & 0.743 & 0.713 & 0.703 & 0.583 & 0.473 & 0.330 & 4 & \\
\hline \multirow{4}{*}{$\Xi$} & Carton boxes & 0.867 & 0.803 & 0.727 & 0.640 & 0.553 & 0.463 & 4 & \multirow{4}{*}{16} \\
\hline & Glass jars & 0.907 & 0.900 & 0.840 & 0.747 & 0.663 & 0.630 & 5 & \\
\hline & Cotton bags & 0.800 & 0.653 & 0.717 & 0.623 & 0.440 & 0.383 & 4 & \\
\hline & Polyethylene bags & 0.697 & 0.613 & 0.630 & 0.587 & 0.433 & 0.293 & 3 & \\
\hline & L.S.D. at $5 \%$ & 0.029 & 0.036 & 0.038 & 0.035 & 0.037 & 0.041 & & \\
\hline Sum D & ing Period X Storage & 13.46 & 12.87 & 12.29 & 11.00 & 9.22 & 7.91 & & \\
\hline
\end{tabular}

Egypt. J. Hort. Vol. 40, No.2 (2013) 


\section{References}

Abd El-Latif, M.E., Hamed, S. and Mattuk H.I. (2001) Influence of pre-treatment and dehydration process on chlorophylls retention of parsley, coriander and peppermint leaves. Egypt. J. Agric. Res., 79 (3), 1111.

Abdalla, M.Y.A., Massoud, H.Y. and Ali, H.A. (2002) Effect of different drying and storage methods on the quality of lemongrass oil (Cymbopogon citratus). J. Agric. Sci. Mansoura Univ., 27(1), 459-468.

Al-Kershi, A.A.G. (2003) Post-harvest packaging and temperature controlled storage of spearmint and sweet basil herbs destined for medicinal and aromatic uses. Ph.D. Thesis, Fac. Agric., Alex Univ., Egypt.

Bohm, V., Kuhnert, S., Rohm, H. and Scholze, G. (2006) Improving the Nutritional Quality of Microwave-vacuum dried strawberries: A preliminary study. Food Sci. Tech. Int., 12(1), 67-75.

Boon, H. and Smith, M. (1999) The botanical pharmacy. The pharmacology of 47 common herbs. (294-296).

Chang Yen, I., Sookram, R. and Mc-Gaw, D. (1996) Yield and chemical composition of essential oils of Grenadian nutmegs. Tropical Agric., 73(4), 301.

Diaz-Maroto, M. C., Perez-Coello, M. S. and Cabezudo, M. D. (2002) Effect of drying method on the volatile oil in bay leaf (Laurus nobilis L.). J. Agricultural and Food Chemistry, 50(16), 4520-4524.

Egyptian Pharmacopoeia (1984) Egyptian Pharmacopoeia, General Organization for Governmental. Printing Office, Ministry of Health, Cairo, Egypt, 31-33.

El-Kady, A.T.M. (2003) Techno chemical studies on some horticulture crops (basil and marjoram). M.Sc. Thesis, Fac. of Agric., Moshtohor, Zagazig Univ ., Egypt.

Gomez, K. A. and Gomez A. A. (1984) Statistical Procedures Res. $2^{\text {nd }}$ ed. John Wiley and Sons, Inc., New York, USA.

Guenther, E. (1961) The Essential Oils. Vol. IV. Individual essential oils of the plant family Umbelliferae. $4^{\text {th }}$ ed. Dr. Van Nostrand Company, Inc. pp. 618-663.

Guenther, Z. and Joseph S. (1978) Handbook Series in Chromatography, CRC press, USA.

Hassan, E.M., Abdallah, N.M., Hussein, A. and Ibrahim, N. (1989) Changes in the physical properties and chemical composition of peppermint (Mentha viridis) dehydrated by three different methods. $2^{\text {nd }}$ Conference of Food Sci. and Technol. for Mediterranean Countries, Cairo, Egypt, 246.

Karabulut, I., Topcu, A. A., Duran, Turan, S. and Ozturk, B. (2007) Effect of hot air drying and sun drying on color values and $\beta$-carotene content of apricot (Prunus armenica L.). Food Science and Technology, 40, 753-758.

Egypt. J. Hort. Vol. 40, No.2 (2013) 
Karawya, M.S., Hifnawy M.S. and El-Hawary S. (1977) Effect of nitrogen fertilizer time of cutting and drying of Mentha piperita L. and Mentha spicata L. Egypt J. Pharm. Sci., 18(4), 405- 422.

Kassem, A.M., El-Batawi, I.E. and Sidky, M.M.A. (2006) Effect of solar energy and other drying methods on quality of some medicinal plants. The $14^{\text {th }}$ Annual Conference of Society of Agr.Eng., Nov., 22, 766-782.

Mazumdar, B.C. and Majumder, K. (2003) Methods of physiochemical analysis of fruits. Daya, House, Delhi, India.

Mohamed, S.M. (2005) Effect of storage on some medicinal plants in Egypt and Morocco. M.Sc. Thesis, Fac. Agric., Cairo Univ., Egypt.

Mohamed, Mona, S.M. (2010) Effect of drying and storage methods on some medicinal and aromatic plants . M.Sc. Thesis, Fac. Agric., Mansoura Univ., Egypt.

Muller, J., Conrad, T., Thome, B. and Muhlbauer, W. (1996) Drying of medicinal plants in a plastics solar drier. Plasticulture., 112,33-41.

Musa,Ö., Arslan, D. and Ünver, A. (2004) Effect of drying methods on the mineral content of basil (Ocimum basilicum L.). Dep. of Food Engineering, Faculty of Agri., Selcuk Univ., Konya 42032, Turkey .

Omidbaigi, R., Sefidkon, F. and Kazemi, F. (2004) Influence of drying methods on essential oil content and composition of Roman chamomile. Flavour and Fragrance Journal. 19,196-198.

Rashed, N. (2002) Effect of fertilization on the growth and storability of some aromatic plants. M.Sc. Thesis, Fac. Agric., Kafr El-Sheikh, Tanta Univ., Egypt.

Rashed, Nahed M.M. and Younis, S.I. (2010) Effect of different package film on the quality of fresh Origanum syriacum, L. Herb. Journal of Applied Sciences Research, 6(1), 6-12.

Refaat, A.M. (1992)Post harvest study on laurel leaves. Bull. Fac. Agric., Cairo Univ., 43(3), 965-976.

Refaat, A.M. and Wahba, H.E. (1998) Some factors affecting lavender plant productivity. Annals Agric. Sci. Ain Shams Univ., 43(1), 273-285.

Simon, J.E., Chadwick, A.F. and Craker, L.E. (1984) Herbs: An indexed bibliography 1971-1980, the scientific literature on selected herbs, and aromatic and medicinal plants of the temperate zone. Archon Books, Hamden, CT.

(Received 11/8/2013; accepted $11 / 11 / 2013)$ 


\title{
تأثير طرق التجفيف و مواد التعبئة على نوعية نبات الزعتر اثثاء \\ فترة التخزين
}

\author{
ربيع محمد مصطفى يوسف و أيمن محمود أحمد حمودة

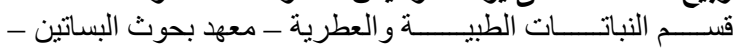 \\ مركز البحوث الزر اعية ـ القاهرة - مصر.
}

تم إجراء هذا البحث خلال موسمين متتاليين (2010-2011) و(2011-2012) بمحطة البساتين بالقصاصين محافظة الاسماعيلية التابعة لمعهد بحوث البراتين البساتين -

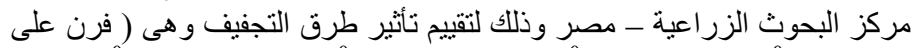

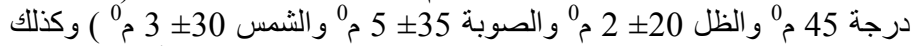

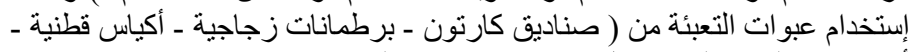

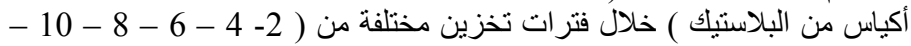
12 شهر ) وذلك على المحتوى من الزيت الطيار وصبغات الكنات الكلوروفيل و الكاروتين لعشب نبات الزعتر

أظهرت النتاتج أن أعلى قيم من النسبة المئوية للزيت الطيار تأتى من إستخدام

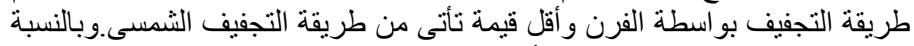

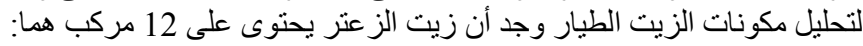
Tricyclene, $\alpha$ - Pinene, Camphene, $\alpha$ - Terpinene, Limonene,1,8-cineol, p- Cymene, Camphor, Linalool, Borneol, \& Limonene : وأن المركبين الاساسيين هما Thymol and Carvacrol Thymol

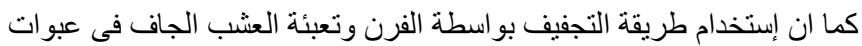

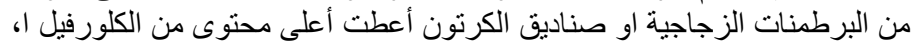

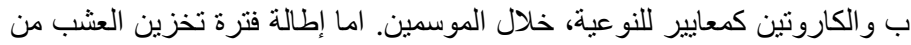

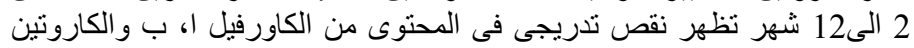

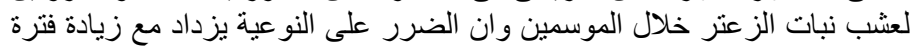
التخزين. 